\title{
Twisting of the spermatic cord: ischemia and reperfusion, toxicogenetic evaluation, and the effects of phosphatidylcholine in pre-clinical trials
}

\author{
H.R.S. Coelho, ${ }^{1,2}$, C.R. Berno ${ }^{1,3}$, G.R. Falcã $0^{4}$, C.R. Hildebrand ${ }^{1}$, \\ R.J. Oliveira ${ }^{1,2,3}$ and A.C.M.B. Antoniolli-Silva ${ }^{1,2}$ \\ ${ }^{1}$ Centro de Estudos em Células Tronco, Terapia Celular e Genética Toxicológica, \\ Hospital Universitário "Maria Aparecida Pedrossian", \\ Empresa Brasileira de Serviços Hospitalares, Campo Grande, MS, Brasil \\ ${ }^{2}$ Programa de Pós-graduação em Saúde e Desenvolvimento na Região Centro-Oeste, \\ Faculdade de Medicina, Universidade Federal de Mato Grosso do Sul, MS, Brasil \\ ${ }^{3}$ Programa de Mestrado em Farmácia, Centro de Ciências Biológicas e da Saúde, \\ Universidade Federal de Mato Grosso do Sul, Campo Grande, MS, Brasil \\ ${ }^{4}$ Faculdade de Medicina, Universidade Federal de Mato Grosso do Sul, \\ Campo Grande, MS, Brasil
}

Corresponding author: A.C.M.B. Antoniolli-Silva

E-mail: andreia.silva@ebserh.gov.br

Genet. Mol. Res. 15 (3): gmr. 15038529

Received February 4, 2016

Accepted May 5, 2016

Published August 29, 2016

DOI http://dx.doi.org/10.4238/gmr.15038529

Copyright $(2016$ The Authors. This is an open-access article distributed under the terms of the Creative Commons Attribution ShareAlike (CC BY-SA) 4.0 License.

\begin{abstract}
Phosphatidylcholine is the main phospholipid present in cell membranes and in lipoproteins, and can interfere with various biological processes. This lipid also has antioxidant activity, and protects against damage caused by free radicals under conditions of ischemia/reperfusion. Therefore, the present study was designed to
\end{abstract}


evaluate toxicogenetic damage caused by twisting of the spermatic cord in ischemia/reperfusion, and whether phosphatidylcholine plays a role in conditions of ischemia/reperfusion in preclinical trials. The results indicate that spermatic cord torsion does not cause genotoxic damage or mutagenesis. A dose of $300 \mathrm{mg} / \mathrm{kg}$ of phosphatidylcholine is toxic and is thus not recommended. However, a dose of $150 \mathrm{mg} / \mathrm{kg}$ does not promote toxicogenetic damage, and though it does not statistically prevent tissue damage occurring from lack of oxygenation and nutrition of testicular cells, it has a tendency to reduce this damage. Therefore, this research suggests that further studies should be conducted to clarify this tendency and to provide a better explanation of the possible therapeutic effects of phosphatidylcholine in cytoprotection of germ cells affected by ischemia/reperfusion.

Key words: Antioxidant; Cell death; Comet assay; Micronucleus assay; Histopathology

\section{INTRODUCTION}

Testicular torsion is a urological emergency characterized by the rotation of the spermatic cord on its own axis. This event causes biochemical and morphological changes in the testes owing to ischemia/reperfusion, and if not diagnosed and treated in time, its effects will be exacerbated because of reperfusion and necrosis of the gonads (Sinha and Swerdloff, 1999).

This urological condition can affect patients of all ages. However, it occurs more frequently from the neonatal period until adolescence (Gunther et al., 2006). Presently, the worldwide incidence of this condition is one case per 4000 men aged $<25$ years (Ringdahl and Teague, 2006). Surgical treatment of this condition involves the manual detorsion of the testes, restoration of their anatomical position, and orchiopexy (Bolln et al., 2006). Orchiectomy and prophylactic contralateral orchiopexy are indicated in cases of testicular necrosis (Sessions et al., 2003).

Widespread testicular ischemia/reperfusion, which can occur during torsion of the spermatic cord, is due to occlusion of the venous return and leads to edema and vascular rupture. Subsequently, arterial occlusion prevents the oxygenation and nutrition of tissues and may cause the death of germ cells and Leydig cells, and even testicular necrosis. Additionally, ischemic organ injury and reperfusion of the contralateral testicle promote histological changes (Jesus, 2000). The damage caused by the reperfusion of the testicle occurs because of oxidative stress via the increased production of reactive oxygen and nitrogen species, which are toxic to cells and lead to membrane lipid peroxidation and apoptosis (Aitken and Roman, 2008; Lee et al., 2012). The combination of these events may cause changes in DNA via disruption of genetic pathways and changes in the cell cycle and cell proliferation, with a consequent increase in apoptotic events (Wei et al., 2013). One possible strategy to protect against these reactive species is endogenous antioxidant defense by the enzymes superoxide dismutase, glutathione peroxidase, catalase, and glutathione-S-transferase (Aitken and Roman, 2008). However, in the case of torsion of the spermatic cord, where increased production of reactive species occurs, therapies based on antioxidants and/or compounds that enhance the antioxidant effect, such as phosphatidylcholine, can be used (Ikeda et al., 2011).

Phosphatidylcholine is the main phospholipid present in cell membranes and

Genetics and Molecular Research 15 (3): gmr.15038529 
lipoproteins and interferes with many biological processes (van Meer, 1989). Its metabolites are important mediators of intracellular signaling (Cui and Houweling, 2002), inflammation (Pompéia et al., 2003), and immunomodulation (Courrèges et al., 2003). It has also been reported that phosphatidylcholine increases the solubility of cholesterol and can therefore change the composition of fatty deposits and inhibit platelet aggregation, reducing the risk of cardiovascular disease (Mel'Chinskaia et al., 2000). Its therapeutic use has also been reported for mental disorders (Adibhatla and Hatcher, 2007), neuronal preservation (Zweigner et al., 2004), liver disease associated with alcohol abuse (Schuller-Perez and San Martin, 1985), and viral infections, including hepatitis (Tsyrkunov, 1992).

Therefore, the present study aimed to evaluate the toxicogenetic damage caused by ischemia and reperfusion due to twisting of the spermatic cord, as well as the effects of phosphatidylcholine on this urological condition in preclinical trials.

\section{MATERIAL AND METHODS}

\section{Chemical agent}

Phosphatidylcholine [Lipostabil ${ }^{\circledR}$, Sanofi-Aventis, France, Lot 1726, 150 and $300 \mathrm{mg} /$ kg body weight (b.w.)] was administered intraperitoneally (ip) in a single dose.

\section{Animals}

Twenty-one adult male Wistar Rattus norvegicus albinus with an average weight of $460 \mathrm{~g}$ were obtained from the Central Animal Facility of the Biological Sciences Center at Universidade Federal de Mato Grosso (UFMS).

The animals were housed in pairs or trios in polypropylene boxes lined with wood shavings, and were fed commercial feed $\left(\mathrm{Nuvital}^{\circledR}\right)$ and filtered water ad libitum. The boxes were maintained on shelves in standardized conditions with a 12/12-h light/dark photoperiod, a temperature of $22^{\circ} \pm 2^{\circ} \mathrm{C}$, and relative humidity of $55 \pm 10 \%$. The experiment was conducted in accordance with the guidelines of the Universal Declaration of Animal Rights and was approved by the Ethics Committee on Animal Use of UFMS under protocol No. 509/2013.

\section{Experimental design}

The animals were randomly divided into three groups (seven animals per group): I) control (ischemia/reperfusion) group; in this group, the left testis was exteriorized, and the spermatic cord was twisted $720^{\circ}$ in a clockwise direction (internal) and maintained in that position in a container with $0.9 \%$ saline at ambient temperature for $2 \mathrm{~h}$, after which the cord was untwisted and the testis was repositioned in the scrotum. Subsequently, the incision was sutured with continuous stitches in a single plane. Fifteen minutes before testicular repositioning, a saline solution was injected (ip) at a dosage of $1.0 \mathrm{~mL} / 100 \mathrm{~g}$ b.w. II) Phosphatidylcholine group (150 mg/kg, PC150) and III) phosphatidylcholine group (300 mg/kg, PC300) animals were subjected to the same procedures performed on the control group, with the exception that the saline solution (ip) was replaced with phosphatidylcholine, with administered doses of 150 and $300 \mathrm{mg} / \mathrm{kg}(i p)$ for groups II and III, respectively.

Euthanasia was performed 60 days after the administration of phosphatidylcholine or

Genetics and Molecular Research 15 (3): gmr.15038529 
$0.9 \%$ saline, using an overdose of anesthetic (ketamine hydrochloride; Fort Godge Laboratory, USA) after collection of the testes for histopathological evaluation.

\section{Surgical procedure}

The animals were anesthetized by an intramuscular injection of ketamine hydrochloride $(50 \mathrm{mg} / \mathrm{kg}$, Fort Godge Laboratory) and xylazine hydrochloride $(10 \mathrm{mg} / \mathrm{kg}$, Burs Veterinary Supply, USA) into the lateral side of the left thigh. After anesthesia, a trichotomy was performed in the left inguinal region. Subsequently, the animals were placed on a surgical board in the supine position, antisepsis was performed with $1 \%$ chlorhexidine and the placement of a fenestrated sterile drape, and an inguinotomy was performed.

The access route was produced by an oblique incision of approximately $1.5 \mathrm{~cm}$ inside the left inguinal region with a No. 15 blade and No. 3 cable, followed by opening the layers of the skin and subcutaneous tissue until visualization of the spermatic cord was possible. The spermatic cord was dissected and isolated using Adson anatomical toothless forceps, curved Kelly forceps (mosquito), and curved Metzenbaum scissors, initiating inferiorly until the left testis was exposed.

The left testis was externalized, and the spermatic cord was manually twisted clockwise in two circles around its own axis (approximately $720^{\circ}$ ). It was maintained in this position in a container with $10 \mathrm{~mL} 0.9 \%$ saline at ambient temperature for $2 \mathrm{~h}$. Subsequently, the testis was repositioned on the left hemi-scrotum, and the wound was sutured with continuous stitches on a single plane with 3-0 polyester sutures (Ethicon, Somerville, NJ, USA).

\section{Biological assays}

\section{Toxicogenetic evaluation}

Twenty-four hours after the administration of phosphatidylcholine or $0.9 \%$ saline (T1), two $20-\mu \mathrm{L}$ peripheral blood samples were collected by puncturing the tail vein, in order to perform the comet and micronucleus assays. Other peripheral blood samples $(20 \mu \mathrm{L})$ were collected for the micronucleus assay $48 \mathrm{~h}(\mathrm{~T} 2)$ and $72 \mathrm{~h}$ (T3) after the administration of phosphatidylcholine or $0.9 \%$ saline.

\section{Comet assay}

The comet assay was performed according to the method described by Oliveira et al. (2015). A $20-\mu \mathrm{L}$ aliquot of peripheral blood was homogenized in $120 \mu \mathrm{L}$ low-meltingpoint agarose $(0.75 \%)$. This solution was deposited on slides covered with normal agarose $(1.5 \%)$. The slides were covered with a glass cover slip and cooled at $4^{\circ} \mathrm{C}$ for $20 \mathrm{~min}$. The coverslips were removed and immersed in freshly prepared lysis solution for $1 \mathrm{~h}$ at $4^{\circ} \mathrm{C}$ while being protected from light. Afterwards, the slides were transferred to an electrophoresis tank containing buffer at $\mathrm{pH}>13.0$ for 20 min at $4^{\circ} \mathrm{C}$ for DNA denaturation. This procedure was followed by electrophoresis at $25.0 \mathrm{~V}$ and $300.0 \mathrm{~mA}(1.25 \mathrm{~V} / \mathrm{cm})$ for $20 \mathrm{~min}$. The slides were neutralized in buffer ( $\mathrm{pH} 7.5,0.4 \mathrm{M}$ Tris- $\mathrm{HCl})$ three times ( 5 min each cycle), air dried, and fixed in absolute ethanol for $10 \mathrm{~min}$. The slides were stained with $100 \mu \mathrm{L}$ ethidium bromide at 20X $10-3 \mathrm{mg} / \mathrm{mL}$ and analyzed on an epifluorescence microscope (model L2000, Bioval ${ }^{\circledR}$ ) at a

Genetics and Molecular Research 15 (3): gmr.15038529 
magnification of 400X with a 420-490 nm excitation filter and a 520-nm barrier filter. Following the procedure of Kobayashi et al. (1995), 100 cells were analyzed per animal, and the comets were classified as class 0 , undamaged cells without a tail; class 1 , cells with a tail that was smaller than the diameter of the nucleoid; class 2, cells with a tail size between one and two times the diameter of the nucleoid; and class 3, cells with a tail two times larger than the diameter of the nucleoid. Apoptotic cells with a completely fragmented nucleoid were not counted. The total score was calculated by summing the values resulting from the multiplication of the total number of cells observed in each damage category by the class value.

\section{Micronucleus test}

The micronucleus assay was performed on peripheral blood samples according to the protocol described by Oliveira et al. (2015). A 20- $\mu \mathrm{L}$ aliquot peripheral blood was placed on a slide covered with $20 \mu \mathrm{L}$ acridine orange $(1.0 \mathrm{mg} / \mathrm{mL})$, and then covered with a cover slip. The slide was maintained at $-20^{\circ} \mathrm{C}$ for a minimum of two weeks. The analysis was performed with an epifluorescence microscope (model L2000, Bioval ${ }^{\circledR}$ ) at a magnification of $400 \mathrm{X}$ with a 420-490 $\mathrm{nm}$ excitation filter and a $520 \mathrm{~nm}$ barrier filter. A total of 2000 cells were analyzed per animal.

\section{Histopathological analysis}

After the 60-day experimental period, the testes were collected, fixed, and maintained in $10 \%$ buffered formalin for $48 \mathrm{~h}$. They were sectioned in the sagittal plane and prepared for histopathological examination. Briefly, after fixation, the tissue sections were dehydrated, cleaned, and embedded in paraffin. The samples were cut on a microtome at a thickness of 5 $\mu \mathrm{m}$, stained with hematoxylin and eosin (H\&E), and examined under a bright field microscope at a magnification of 1000X (model Eclipse e-200, Nikon ${ }^{\circledR}$ ).

Histopathological evaluation was performed by a double-blind model according to the damage scale proposed by Cosentino et al. (1985) and modified by Urt Filho et al. (2012). Damage was classified as: grade 1, normal testicular architecture and orderly arrangement of germ cells; grade 2, lower histological organization, loss of cohesion between germ cells, and closed seminiferous tubules; grade 3, higher disorganization of testicular architecture, germ cells with pyknotic and retracted nuclei, and seminiferous tubules with poorly defined edges; and grade 4, presence of occluded seminiferous tubules and coagulative necrosis of germ cells.

\section{Statistical analysis}

The values are repoted as means \pm standard error of the mean or percentages. Data were analyzed using ANOVA and Tukey, Kruskal-Wallis, and chi-square tests, according to their nature and distribution, using the GraphPad Prism software version 2.3 (Graph-Pad Software Inc., San Diego, CA, USA). The significance level was set at $\mathrm{P}<0.05$.

\section{RESULTS}

\section{Biometric parameters}

The animals were randomly divided into the experimental groups, and statistically

Genetics and Molecular Research 15 (3): gmr.15038529 
significant differences were not observed between the control group and the groups treated with phosphatidylcholine. However, a significant decrease was observed in the weight of the PC300 group compared to that of the PC150 group $(\mathrm{P}<0.05)$ (Figure 1).

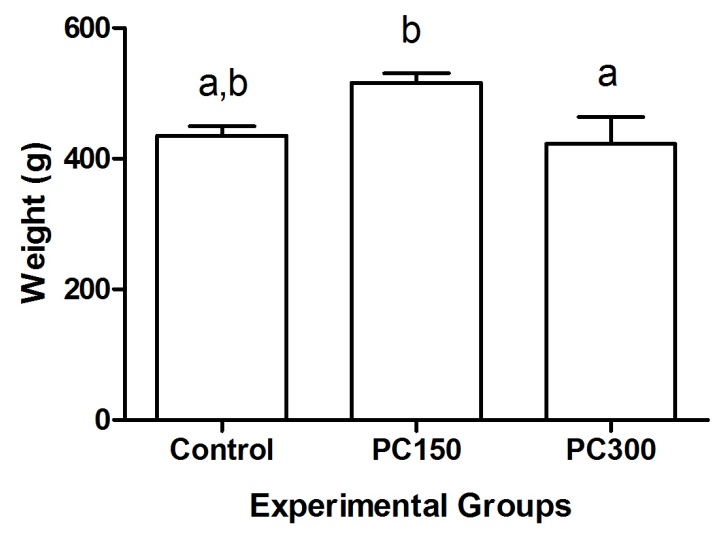

Figure 1. Biometric parameters. Data are reported as means $\pm \mathrm{SE}$ of animal weight at the end of the experimental period. Statistical test: ANOVA/Tukey $(\mathrm{P}<0.05)$. Different letters indicate statistically significant differences.

\section{Toxicogenetic evaluation}

The analysis of the frequency of genetic changes, according to the comet and micronucleus assays, indicated that neither testicular twisting nor treatment with phosphatidylcholine at the two concentrations tested caused genotoxic or mutagenic damage (Figure 2).
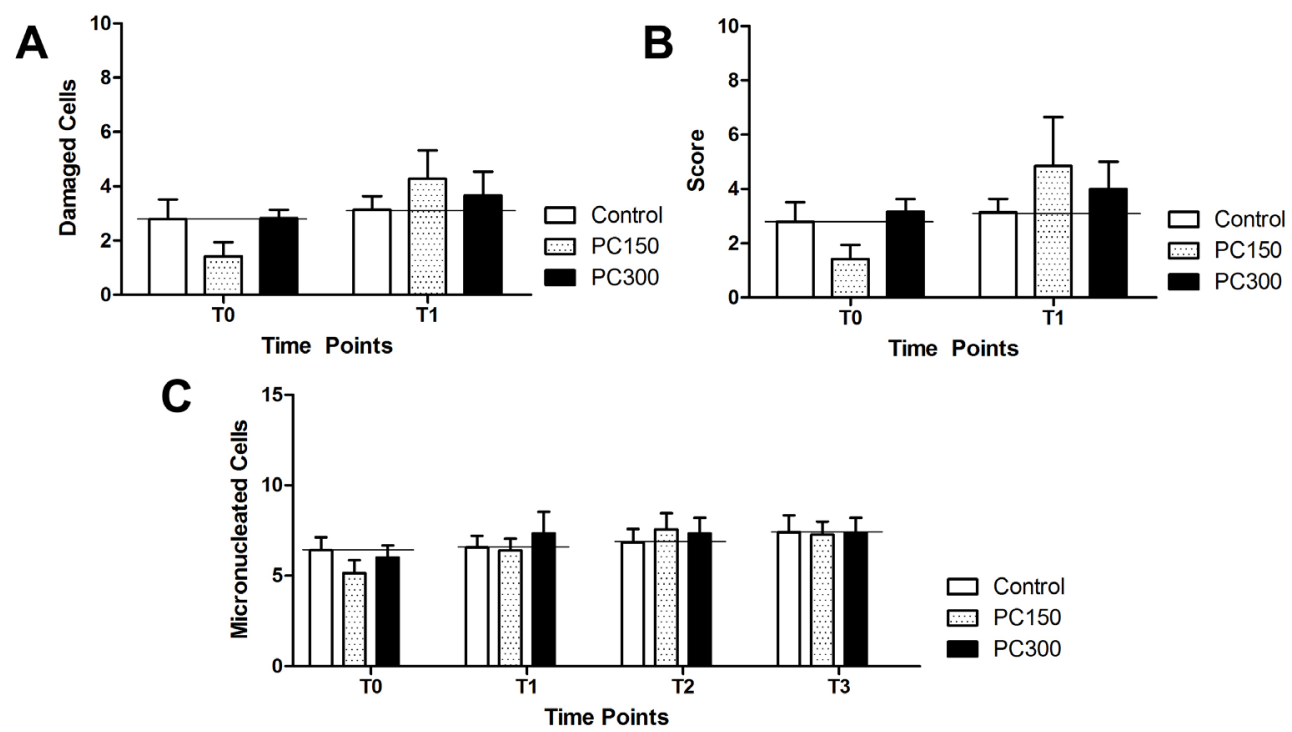

Figure 2. Genetic changes. Results are reported as means \pm SE. A. Frequency of damaged cells in the peripheral blood, measured using the comet assay. B. Comet assay score in the peripheral blood. C. Frequency of micronucleated cells in the peripheral blood, measured using the micronucleus assay. Statistical test: ANOVA $(\mathrm{P}>0.05)$.

Genetics and Molecular Research 15 (3): gmr.15038529 


\section{Survival analysis and histopathological examination}

The histological examination indicated no significant improvement in histological damage and mortality rate in the groups evaluated. However, the PC150 group showed a viability of $100 \%$ and a tendency toward the reduction in histological damage, indicating an important biological result. In the PC300 group, there was less reduction in histological damage, and the mortality rate was $57.14 \%$ (Figure 3 ).

A

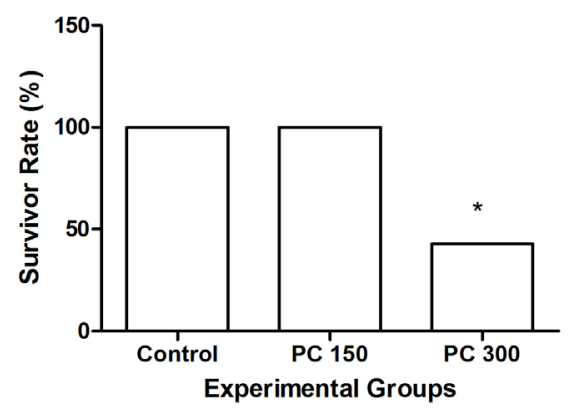

B

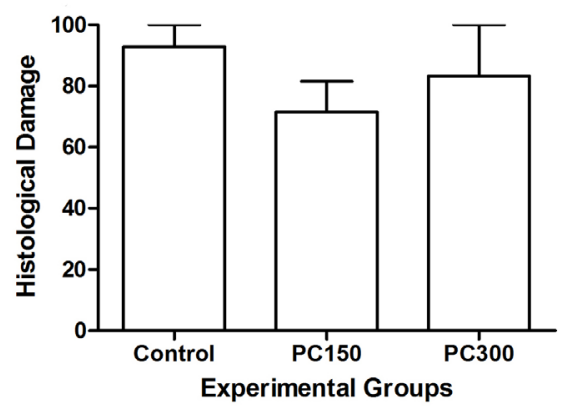

Figure 3. Animal survival (A) and means \pm SE of the frequency of histological damage (B) according to Cosentino et al. (1985) and Urt Filho et al. (2012). Damage was classified as: grade 1, normal testicular architecture and orderly arrangement of germ cells; grade 2, lower histological organization, loss of cohesion between germ cells, and closed seminiferous tubules; grade 3, higher disorganization of testicular architecture, germ cells with pyknotic and retracted nuclei, and seminiferous tubules with poorly defined edges; and grade 4, presence of occluded seminiferous tubules and coagulative necrosis of germ cells. Statistical test: chi-square test $(\mathrm{P}<0.05)$ (A). *Statistically significant differences. B. Kruskal-Wallis test $(\mathrm{P}>0.05)$.

A detailed analysis of the histological parameters indicated that the process of ischemia/reperfusion caused a histological damage score of $185.71 \pm 41.85$ with changes classified as Classes 1 and 3. The administration of PC150 reduced the score to $100.00 \pm$ 34.50. Data from the PC150 group showed a reduction in Class 3 damage and an increase in the analyzed fields without histological damage (Class 0). However, the PC300 treatment increased the histological damage score to $216.66 \pm 83.33$ and increased the frequency of Class 3 damage (Table 1).

Table 1. Mean values $\pm \mathrm{SE}$ of histological classes of damage and score.

\begin{tabular}{l|c|c|c|c|c}
\hline \multirow{2}{*}{ Experimental groups } & \multirow{2}{*}{ Score } & \multicolumn{4}{|c}{ Classes of damage* } \\
\cline { 3 - 6 } & & Class 0 & Class 1 & Class 2 & Class 3 \\
\hline Control & $185.71 \pm 41.85$ & $7.14 \pm 7.14$ & $42.85 \pm 17.00$ & $0.00 \pm 0.00$ & $42.85 \pm 20.20$ \\
\hline PC150 & $121.42 \pm 40.62$ & $28.57 \pm 10.10$ & $42.85 \pm 13.04$ & $7.14 \pm 7.14$ & $21.42 \pm 14.86$ \\
\hline PC300 & $216.66 \pm 83.33$ & $16.66 \pm 16.66$ & $16.66 \pm 16.66$ & $7.14 \pm 7.14$ & $66.66 \pm 33.33$ \\
\hline
\end{tabular}

*According to Consentino et al. (1985) and Urt Filho et al. (2012). SE: standard error. Statistical test: ANOVA/ Tukey $(\mathrm{P}>0.05)$.

\section{DISCUSSION}

Cases of sterility and infertility are increasing, and these important public health problems are being aggravated on a global scale (Nachtigall, 2006). The causes of these 
complications include genetic, environmental, and idiopathic factors (Macaluso et al., 2010). Some urological diseases are also included among the causes, including urogenital tract infections (Sobinoff et al., 2015), cryptorchidism (Chung and Brock, 2011), varicocele (Shafi et al., 2014), and torsion of the spermatic cord mediated by ischemia/reperfusion processes (Ahmed et al., 2000). In the latter case, studies have primarily examined the effects of ischemia/ reperfusion (and consequently, of hypoxia) on the germ cells, damage to the contralateral testis, and reperfusion (Antoniolli-Silva et al., 2005).

The protocols and results described in the literature are diverse, limiting data comparison, particularly with regard to the strategies that promote ischemia/reperfusion. These strategies include the twisting of the spermatic cord to different degrees $\left(180^{\circ}\right.$ to $\left.1080^{\circ}\right)$ and ligation of the spermatic artery (Sessions et al., 2003). However, the most widely used models to evaluate the effect of ischemia/reperfusion on spermatogenesis in the adult rat involve a $720^{\circ}$ rotation for $1-6 \mathrm{~h}$ and persistent damage after 60 days, which may even be irreversible (Becker and Turner, 1995; Silva et al., 2005). Therefore, the present study selected the protocol of Silva et al. (2005) with modifications, and a 2-h period of ischemia/reperfusion.

According to Turner and Brown (1993), after at least $1 \mathrm{~h}$ of ischemia/reperfusion, tissue damage can be quantified in the testis. Therefore, a period of approximately $1 \mathrm{~h}$ is indicated for the therapeutic effect antioxidant therapies for protection of the germ cells. Therefore, in the present study, we used phosphatidylcholine, which has antioxidant activity (Nwosu et al., 1997).

The ischemic/reperfusion state during the twisting of the spermatic cord causes the release of free radicals (Lee et al., 2012), which generally cause damage to DNA and RNA (Nikitaki et al., 2015) and the peroxidation of membrane lipids, triggering the apoptotic signaling pathway (Acevedo-Morantes et al., 2012). However, few studies have evaluated the correlation between urologic diseases, fertility, and genetic damage. Therefore, the present study is the first to associate the absence of genetic changes (genotoxic and mutagenic) and testicular ischemia/ reperfusion, as the comparison of genetic lesions before ischemia/reperfusion (T0) and T1, T2, and T3 after ischemia/reperfusion showed that comet frequency (frequency of damaged cells and classification scores) and the frequency of micronuclei both remained unchanged. Although previous studies have reported that increased levels of free radicals are capable of affecting the germinal epithelium, these concentrations were not sufficient to cause DNA damage in peripheral blood, as demonstrated by the comet and micronucleus assays, which are important biomarkers in the field of genetic toxicology (Vasquez, 2010) and are used by regulatory agencies to evaluate toxicity and monitoring (Maffei et al., 2005). It is of note that these assays, when associated with teratogenicity and dominant lethal studies, help relate reduced fertility and increased changes in reproductive performance with embryo-fetal development (David et al., 2014; Oliveira et al., 2015) and with possible pathological processes.

Regarding the administration of phosphatidylcholine, it was observed that this compound is not genotoxic or mutagenic, considering that no significant changes were observed between the PC150 and PC300 groups when the condition at T0 was compared with conditions at T1, T2, and T3. Biometric data also indicated no statistically significant differences between the control group and the two phosphatidylcholine groups. However, although genetic toxicity or reduced b.w. was not observed, $57.14 \%$ of the animals that received an ip dose of $300 \mathrm{mg} /$ $\mathrm{kg}$ b.w. died in the first few hours after treatment with phosphatidylcholine. Therefore, this dose may not cause apparent toxicity as shown by the decrease in b.w., opacity of the eyes and hair, mucosal dryness, hair bristling, behavior and motility changes, and lower food and water intake, which are important indicators of toxicity (Oliveira et al., 2015). However, this dose is

Genetics and Molecular Research 15 (3): gmr.15038529 
close to the LD50, the dose capable of killing $50 \%$ of the animals in the population evaluated, which precludes its use. Furthermore, the absence of mortality and signs of intoxication together with the absence of genotoxic and mutagenic damage favor the use of a dose of 150 $\mathrm{mg} / \mathrm{kg}$ for antioxidant therapy against damage caused by ischemia/reperfusion.

One possible strategy to protect against these reactive species is the endogenous antioxidant defense performed by the enzymes superoxide dismutase, glutathione peroxidase, catalase, and glutathione-S-transferase (Aitken and Roman, 2008). However, in the case of torsion of the spermatic cord, characterized by the increased production of reactive species, antioxidant therapies and/or compounds that enhance these effects, including phosphatidylcholine, can be used (Ikeda et al., 2011) to prevent cytotoxic injury to the tissues subjected to lack of nutrition and oxygenation.

This absence of DNA damage and toxicity seen with the lowest dose tested reinforces the indication of phosphatidylcholine as an antioxidant therapy for the protection of germ cells because of its activity against free radicals. In this respect, other experimental studies have demonstrated the efficacy of other drugs, including superoxide dismutase, catalase, mannitol, allopurinol, vitamin E, N-acetylcysteine, other iron-chelating compounds, angiotensin converting inhibitors, and calcium channel antagonists, for the attenuation of ischemia/ reperfusion lesions (Silva-Jr et al., 2002; Silva et al., 2005).

The mitochondrial damage caused by ischemia/reperfusion leads to a decrease in the activity of reduced nicotinamide adenine dinucleotide (NADH), the ADP/ATP carrier, and ATP synthase. In addition, the concentrations of phospholipase A2, calcium, and free radicals are increased. It is known that the combination of these events leads to cell death and other possible changes via changes in the permeability of the outer mitochondrial membrane (SilvaJr et al., 2002). Considering that phosphatidylcholine has antioxidant activity (Nwosu et al., 1997) and is present in the cell membrane of most cells, its concentration and composition affect the integrity and function of cell membranes, particularly cellular permeability, by increasing the solubility of cholesterol (Zocher et al., 2013). These characteristics favor the use of phosphatidylcholine to prevent the damage caused by ischemia/reperfusion. However, in the present study, the histological examination indicated no significant differences between the control group and the group that received the lowest dose of phosphatidylcholine; however, an improvement in the histological damage score was observed.

Therefore, considering the potential therapeutic efficacy of this compound, further studies should be conducted to clarify this tendency, as well as the therapeutic effects of phosphatidylcholine for the protection of germ cells in testes subjected to ischemia/reperfusion.

\title{
Conflicts of interest
}

The authors declare no conflict of interest.

\section{ACKNOWLEDGMENTS}

\author{
Research funded by FUNDECT.
}

\section{REFERENCES}

Acevedo-Morantes CY, Meléndez E, Singh SP and Ramírez-Vick JE (2012). Cytotoxicity and Reactive Oxygen Species Generated by Ferrocenium and Ferrocene on MCF7 and MCF10A Cell Lines. J. Cancer Sci. Ther. 4: 271-275.

Genetics and Molecular Research 15 (3): gmr.15038529 
Adibhatla RM and Hatcher JF (2007). Role of lipids in brain injury and diseases. Future Lipidol. 2: 403-422. http://dx.doi. org/10.2217/17460875.2.4.403

Ahmed FA, Whelan J, Jequier AM and Cummins JM (2000). Torsion-induced injury in rat testes does not affect mitochondrial respiration or the accumulation of mitochondrial mutations. Int. J. Androl. 23: 347-356. http://dx.doi. org/10.1046/j.1365-2605.2000.00255.x

Aitken RJ and Roman SD (2008). Antioxidant systems and oxidative stress in the testes. Oxid. Med. Cell. Longev. 1: 1524. http://dx.doi.org/10.4161/oxim.1.1.6843

Becker Jr EJ and Turner TT (1995). Endocrine and exocrine effects of testicular torsion in the prepubertal and adult rat. J. Androl. 16: 342-351.

Bolln C, Driver CP and Youngson GG (2006). Operative management of testicular torsion: current practice within the UK and Ireland. J. Pediatr. Urol. 2: 190-193. http://dx.doi.org/10.1016/j.jpurol.2005.07.006

Chung E and Brock GB (2011). Cryptorchidism and its impact on male fertility: a state of art review of current literature. Can. Urol. Assoc. J. 5: 210-214. http://dx.doi.org/10.5489/cuaj.1010

Cosentino MJ, Nishida M, Rabinowitz R and Cockett ATK (1985). Histological changes occurring in the contralateral testes of prepubertal rats subjected to various durations of unilateral spermatic cord torsion. J. Urol. 133: 906-911.

Courrèges MC, Benencia F, Uceda A and Monserrat AJ (2003). Effect of dietary choline deficiency on immunocompetence in wistar rats. Nutr. Res. 23: 519-526. http://dx.doi.org/10.1016/S0271-5317(02)00544-4

Cui Z and Houweling M (2002). Phosphatidylcholine and cell death. Biochim. Biophys. Acta 1585: 87-96. http://dx.doi. org/10.1016/S1388-1981(02)00328-1

David Nd, Mauro MdeO, Gonçalves CA, Pesarini JR, et al. (2014). Gochnatia polymorpha ssp. floccosa: bioprospecting of an anti-inflammatory phytotherapy for use during pregnancy. J. Ethnopharmacol. 154: 370-379. http://dx.doi. org/10.1016/j.jep.2014.04.005

Gunther P, Schenk JP, Wunsch R, Holland-Cunz S, et al. (2006). Acute testicular torsion in children: the role of sonography in the diagnostic workup. Eur. Radiol. 16: 2527-2532. http://dx.doi.org/10.1007/s00330-006-0287-1

Ikeda R, Ishii K, Hoshikawa Y, Azumi J, et al. (2011). Reactive oxygen species and NADPH oxidase 4 induced by transforming growth factor b1 are the therapeutic targets of polyenylphosphatidylcholine in the suppression of human hepatic stellate cell activation. Inflamm. Res. 60: 597-604. http://dx.doi.org/10.1007/s00011-011-0309-6

Jesus LE (2000). Acute scrotum. Rev. Col. Bras. Cir. 27: 271-278.

Kobayashi H, Sugiyama C, Morikawa Y, Hayashi M, et al. (1995). A comparison between manual microscopic analysis and computerized image analysis in the single cell gel electrophoresis assay. MMS Commun. 3: 103-115.

Lee JW, Kim JI, Lee YA, Lee DH, et al. (2012). Inhaled hydrogen gas therapy for prevention of testicular ischemia/ reperfusion injury in rats. J. Pediatr. Surg. 47: 736-742. http://dx.doi.org/10.1016/j.jpedsurg.2011.09.035

Macaluso M, Wright-Schnapp TJ, Chandra A, Johnson R, et al. (2010). A public health focus on infertility prevention, detection, and management. Fertil. Steril. 93: 16.e1-16.e10. http://dx.doi.org/10.1016/j.fertnstert.2008.09.046

Maffei F, Buschini A, Rossi C, Poli P, et al. (2005). Use of the Comet test and micronucleus assay on human white blood cells for in vitro assessment of genotoxicity induced by different drinking water disinfection protocols. Environ. Mol. Mutagen. 46: 116-125. http://dx.doi.org/10.1002/em.20139

Mel'chinskaia EN, Gromnatskiı̌ NI and Kirichenko LL (2000). [Hypolipidemic effects of alisat and lipostabil in patients with diabetes mellitus]. Ter. Arkh. 72: 57-58.

Nachtigall RD (2006). International disparities in access to infertility services. Fertil. Steril. 85: 871-875. http://dx.doi. org/10.1016/j.fertnstert.2005.08.066

Nikitaki Z, Hellweg CE, Georgakilas AG and Ravanat JL (2015). Stress-induced DNA damage biomarkers: applications and limitations. Front Chem. 3: 35. http://dx.doi.org/10.3389/fchem.2015.00035

Nwosu CV, Boyd LC and Sheldon B (1997). Effect of fatty acid composition of phospholipids on their antioxidant properties and activity index. J. Am. Oil Chem. Soc. 74: 293-297. http://dx.doi.org/10.1007/s11746-997-0139-4

Oliveira RJ, Mantovani MS, Pesarini JR, Mauro MO, et al. (2015). 6-Dimethylaminopurine and cyclohexamide are mutagenic and alter reproductive performance and intrauterine development in vivo. Genet. Mol. Res. 14: 834-849. http://dx.doi.org/10.4238/2015.February.2.8

Pompéia C, Cury-Boaventura MF and Curi R (2003). Arachidonic acid triggers an oxidative burst in leukocytes. Braz. J. Med. Biol. Res. 36: 1549-1560. http://dx.doi.org/10.1590/S0100-879X2003001100013

Ringdahl E and Teague L (2006). Testicular torsion. Am. Fam. Physician 74: 1739-1743.

Schuller-Perez A and San Martin FG (1985). Controlled study using multiply-unsaturated phosphatidylcholine in comparison with placebo in the case of alcoholic liver steatosis. Med. Welt 72: 517-521.

Sessions AE, Rabinowitz R, Hulbert WC, Goldstein MM, et al. (2003). Testicular torsion: direction, degree, duration and disinformation. J. Urol. 169: 663-665. http://dx.doi.org/10.1016/S0022-5347(05)63987-0

Genetics and Molecular Research 15 (3): gmr.15038529 
Shafi H, Esmaeilzadeh S, Delavar MA, Haydari FH, et al. (2014). Prevalence of Varicocele among primary and secondary infertile men: association with occupation, smoking and drinking alcohol. N. Am. J. Med. Sci. 6: 532-535. http:// dx.doi.org/10.4103/1947-2714.143285

Silva AC, Ortiz V, Silva RA and Tognini JR (2005). [Effect of allopurinol on rat testicles morphology, submitted to ischaemia for spermatic cord torsion followed by reperfusion]. Acta Cir. Bras. 20: 468-472. http://dx.doi.org/10.1590/ $\underline{\mathrm{S} 0102-86502005000600013}$

Silva-Jr OC, Centurion S, Pacheco EG, Brisotti JL, et al. (2002). Basics Aspects of the ischemia reperfusion injury and of the ischemic preconditioning. Acta Cir. Bras. 17: 86-100.

Sinha Hikim AP and Swerdloff RS (1999). Hormonal and genetic control of germ cell apoptosis in the testis. Rev. Reprod. 4: 38-47. http://dx.doi.org/10.1530/ror.0.0040038

Sobinoff AP, Dando SJ, Redgrove KA, Sutherland JM, et al. (2015). Chlamydia muridarum infection-induced destruction of male germ cells and sertoli cells is partially prevented by Chlamydia major outer membrane protein-specific immune CD4 cells. Biol. Reprod. 92: 27. http://dx.doi.org/10.1095/biolreprod.114.124180

Tsyrkunov VM (1992). [Lipostabil in the treatment of viral hepatitis B in subjects who abuse alcohol]. Klin. Med. (Mosk.) 70: $75-78$

Turner TT and Brown KJ (1993). Spermatic cord torsion: loss of spermatogenesis despite return of blood flow. Biol. Reprod. 49: 401-407. http://dx.doi.org/10.1095/biolreprod49.2.401

Urt Filho A, Inouye CM, Pontes JCDV, Silva AC, et al. (2012). Propofol effects on the morphology of rat testes subjected to testicular ischemia-reperfusion. Acta Cir. Bras. 27: 172-178. http://dx.doi.org/10.1590/S0102-86502012000200013

van Meer G (1989). Lipid traffic in animal cells. Annu. Rev. Cell Biol. 5: 247-275. http://dx.doi.org/10.1146/annurev. cb.05.110189.001335

Vasquez MZ (2010). Combining the in vivo comet and micronucleus assays: a practical approach to genotoxicity testing and data interpretation. Mutagenesis 25: 187-199. http://dx.doi.org/10.1093/mutage/gep060

Wei SM, Yan ZZ and Zhou J (2013). Involvement of reactive oxygen species and TATA box-binding protein-related factor 2 in testicular torsion/detorsion-induced injury. Urology 81: 466.e9-466.e14. http://dx.doi.org/10.1016/j. urology.2012.09.021

Zocher F, van der Spoel D, Pohl P and Hub JS (2013). Local partition coefficients govern solute permeability of cholesterolcontaining membranes. Biophys. J. 105: 2760-2770. http://dx.doi.org/10.1016/j.bpj.2013.11.003

Zweigner J, Jackowski S, Smith SH, van der Merwe M, et al. (2004). Bacterial inhibition of phosphatidylcholine synthesis triggers apoptosis in the brain. J. Exp. Med. 200: 99-106. 